\title{
SOUTH SUDAN SECESSION: MODELLING THE FISCAL SHOCK AND ITS SPILLOVER EFFECTS
}

\author{
Ibrahim A. Onour ${ }^{1}$ \\ University of Khartoum
}

\begin{abstract}
:
In this article we set up a macroeconomic model designed to describe how a small and open economy endures political uncertainty arising from a country splitting into two independent parts. According to our findings in this paper, stabilization of asset markets in either country at the post-secession era depends on political stability, which will impact on foreign currency inflows to each country. Our model predicts that if political unrest continues after the split, the foreign currency reserves of each other country's Central Bank will deteriorate over time, possibly leading to domestic depreciation of the local currency in terms of hard currencies. The model also predicts that an expanding budget deficit and declining official reserves will eventually force governments to abandon fixed exchange rate systems in favor of more flexible ones, resulting in further acceleration of both the domestic inflation rate and the domestic money growth rate. As a result, the post-secession period is likely to be characterized by economic instability and political unrest in the two sides unless economic cooperation between the two countries is maintained.
\end{abstract}

Keywords: Parallel rate, Official rate, Stability, Steady-state. JEL: C10, C50, G10.

\section{Resumen:}

En este artículo utilizamos un modelo macroeconómico diseñado para describir cómo economías de pequeña escala y abiertas al exterior se enfrentan a la incertidumbre política derivada de la separación de un país en dos partes independientes. Según nuestros resultados en este artículo, la estabilización del mercado de activos en cualquiera de los dos países dependerá de la estabilidad política, la cual impacta en los flujos de divisas extranjeras en ambos países. Nuestro modelo predice que si la inestabilidad política se mantiene tras la división, las reservas de divisas extranjeras de ambos bancos centrales se deteriorarán progresivamente, lo cual posiblemente llevará a una depreciación doméstica de la divisa local en términos de divisas extranjeras. El modelo también predice que un déficit fiscal en expansión y un declive de las reservas oficiales forzará en último término a abandonar cualquier sistema cambiario fijo a favor de sistemas más flexibles, lo cual resultará en una mayor aceleración tanto de la tasa de inflación doméstica y de la tasa de crecimiento del dinero a nivel local. Como resultado, el periodo postsecesión probablemente estará caracterizado por la inestabilidad económica y política en ambos países a no que se mantenga la cooperación económica.

Palabras clave: Tipo cambiario paralelo, tipo cambiario oficial, tipo fijo, JEL: C10, C50, G10.

Copyright (C) UNISCI, 2013.

The views expressed in these articles are those of the authors, and do not necessarily reflect the views of UNISCI. Las opiniones expresadas en estos artículos son propias de sus autores, y no reflejan necesariamente la opinión de UNISCI.

\footnotetext{
${ }^{1}$ Ibrahim A. Onour is a professor of Quantitative Finance at the School of Management Studies, University of Khartoum. He has taught in a number of Universities in the Middle East, Africa, and Canada. He has published extensively in international and regional journals in the area of financial economics.

Email: onour@uofk.edu.
} 


\section{Introduction}

Government of Sudan and the Sudan People's Liberation Movement/Army (SPLM/A) put an end to a 21-year old civil war, by granting Southern Sudan a regime of semi-autonomy within Sudan, which after a referendum on Southern self-determination celebrated in early 2011 led to full independence of South Sudan on 9 July 2011.

Under the CPA, during the interim period before the celebration of the Referendum, the two sides agreed to equally divide the revenue from oil produced in the South, which constituted the source of about a 75 percent of foreign currency for the Sudanese government in the North, with the rest coming from the export of primary agriculture products and foreign investment flows. After South Sudan approved secession from the Republic of Sudan the financial system in Sudan went through substantial changes, as the government of Sudan failed to take any serious measures to adapt to the big shock. Making the matter even worse for Sudan were the ongoing US sanctions imposed since 1997, precluding major governmentowned companies the access to the US financial system and barring their use of US dollar in international financial transactions. Due to the significant drop in the official foreign currency reserves mostly caused by the crude oil price fall of 2009, the government imposed quantitative restrictions on selling foreign currencies to individuals and business entities and required thorough documentation to legitimize the transfer of foreign currencies.

Since early 2011 (the year of secession), speculation has been rising by investors and currency traders that the government reserve level is deteriorating. That itself has added heavy presure on foreign currency demand in the parallel market. To curb speculative effects on foreign exchange markets the Central Bank decided to tighten control on exchange bureaux by enforcing additional restrictions on foreign exchange sales and cracking down on black marketeers of foreign currencies. As a result, since South Sudan's secession a dual foreign exchange market has appeared, with an official exchange rate, managed and determined by the Central Bank, and a freely floating parallel (illegal) market, highly sensitive to speculations and rumors about the economic and the political situation in the country. ${ }^{2}$

The economic stability in Sudan at the current time depends on a political stability in the country which is dependent on the resolution of contentious issues related to the demarcation of the North-South border. Notwhithstanding that, there is still a high probability that the two sides reach an agreement in favor of a limited economic cooperation as the South crude oil needs to flow through the pipelines and refineries in Sudan, the only possible outlet for the South oil export at the current time.

The remaining parts of the paper are structured as follows. Section two outlines the literature review; section three presents the macroeconomic model; section four illustrates a dynamic analysis of different shocks; and the final section concludes the study.

\section{Literature Review}

In the past two decades a voluminous literature has emerged which investigates the impact of political and social unrest on asset markets. The literature on this area can be categorized into

\footnotetext{
${ }^{2}$ The official exchange rate system currently is a managed float system, in which the central bank calculates an indicative rate based on previous day transactions and intervenes in the market if quotes break away from a plus/minus 3 percent margin around that rate.
} 
two groups. The first group investigates the behavior of asset markets under political unrest and regime shifts. ${ }^{3}$ Another group of papers has focused on the volatility of the stock market prices in the US and in some West European countries during the World War II period to suggest that high volatility in stock markets returns is highly correlated with adverse political and social unrests. ${ }^{4}$

\section{The Macroeconomic Model}

The macroeconomic model is the result of the optimal decisions of various decision-making agents in the economy. Private sector producers choose output and input levels for both home goods and export goods. Inputs include both labour and imported producer goods. Firms also decide how much of any export revenue must be diverted to the foreign exchange markets by under-invoicing export sales and over-invoicing import bills. Households choose how much of their total financial wealth must be held in domestic currency, and how much in foreign currency. Finally, the government determines both its fiscal stance and financing and the rules for pricing and rationing in the official foreign exchange market. We will deal with each of them in turn and then assemble the various decision rules into a steady-state equilibrium conditions for the two parts of foreign exchange markets.

\subsection{Domestic Producers' Decisions}

Domestic firms can produce goods either for home consumption or for export. Exports are exogenously determined, as they depend mainly on international terms of trade. Home goods (y) have a Cobb-Douglas production function with imported producer goods $\mathrm{I}_{\mathrm{p}}$ and domestic labour $\mathrm{L}_{\mathrm{y}}$ as the only inputs:

$$
Y \leq I_{p}^{(1-\alpha)} L_{y}^{\alpha}, \quad 0 \leq \alpha \leq 1
$$

It is assumed that there is a quasi-fixed exchange rate denoted as e, applicable to some official transactions, and a freely floating nominal exchange rate, denoted as b, mainly applicable to parallel market transactions. ${ }^{5}$ This latter rate takes whatever level is required to achieve asset market equilibrium. In the remaining parts of the paper we will refer to the quasi-fixed rate as the official rate, and the free rate by the parallel rate.

\footnotetext{
${ }^{3}$ Frey B., and Kutcher M (2000): "History as reflected in capital markets: The case of World War 2" The Journal of Economic History, 60, pp. 468-496. Frey B., Kucher M (2001): "Wars and Markets: How Bond Values Reflect the Second World War", Economica, 68, pp. 317-333. Brown W. and Burdekin R. (2002): "German Debt Traded in London during the second World War, a British perspective on Hitler", Economica, 69, pp. 655-669. Oosterlinck K. (2003): “The Bond Market and the legitimacy of Vicky France”, Explorations in Economic History, 40, pp. 326- 344. Frey B. and Waldenstrom D. (2004): "Markets Work in War: WWII Reflected in the Zurich and Stockholm Bond Markets", Financial History Review, 11, pp. 51-67.

4 Bittlingmayer G. (1998): "Output, Stock Volatility and Political Uncertainty in a Natural Experiment: Germany, 1940-80", Journal of Finance, 53, pp. 2243- 2257. Voth H-J (2001): "Inflation, Political Instability and Stock Market Volatility in Interwar Germany", UPF Economic Working Papers, p. 535.

${ }^{5}$ It is important to realize that the parallel market in this sense is not a black market because it is officially recognized market by the government, and basic reason for this is that the government want to deter emergence of black market for foreign exchange.
} 
The domestic currency purchase price of imported producer goods is the foreign currency price $P^{*}{ }_{m}$ multiplied by the free exchange rate relevant for competitive purchases. Competitive purchases of imported producer goods will always be made at the parallel rate $b$, since the government impose restrictions for purchases at the official rate.

The government stipulates that private firms convert a portion, $(0<\phi<1)$ of their export proceeds at the parallel rate $b$, and the remaining part at the official rate, e which is always lower than $b$.

Despite foreign exchange regulations, firms can divert additional export proceeds illegally at the parallel rate b, by under-invoicing export procceds. As a result, the decision of how much of export proceeds to surrender at the official rate versus the parallel rate depends on the size of $\phi$, which will determines the amount of export proceeds to evade foreign exchange regulations.

The income of domestic firms consists of revenue from goods produced for domestic consumption and revenue from export. The expenditure side includes imported capital goods and labour cost for both export and domestic consumption goods. It is also included in the expenditure side the cost of under-invoicing export revenue, which is assumed as a linear function of $\phi$, or more specifically $(\phi / 2)$. Thus, firms' decision rules for all the choices above are found by maximising their profit function:

$$
\operatorname{Max}\left[p_{y} Y+\left\{\phi b(1-(\phi / 2)+(1-\phi) e\} X-b P^{*}{ }_{m} I_{p}-W\left(L_{x}+L_{y}\right)\right]\right.
$$

With respect to $L_{y}, I_{p}$ and $\Phi$, subject to production technology constraint and to the usual nonnegativity restrictions. The first order conditions for $I_{p}, L_{y}$ and $\Phi$ are:

$$
\begin{aligned}
& P_{y}(1-\alpha) I_{p}^{-\alpha} L_{y}^{\alpha}=P^{*}{ }_{m} b \\
& P_{y} \alpha Y / L_{y}=W \\
& \Phi=(1-1 / \pi)
\end{aligned}
$$

Where $\pi=b / e$, refers to the parallel rate premium, and $P^{*}{ }_{m}$ is the dollar value of import price. Concavity of equation (5) implies that, while rising premium induces diversion of foreign currency from the official market to the parallel market by under-invoicing export revenue, it does at a decreasing rate due to higher penalty costs when the size of underinvoicing increases.

After a few manipulations and substitutions of equations (3) and (4) we get:

$$
P_{y}=P^{*}{ }_{m} b\left(I_{p} / L_{y}\right)^{\alpha}+w\left(I_{p} / L_{y}\right)^{\alpha-1}
$$


When the ratio of capital and labour inputs $\left(I_{p} / L_{y}\right)$ is combined in fixed proportions, equation (6) reduces to:

$$
P_{y}=\beta_{1} P_{m}^{*} b+\beta_{2} w
$$

where $\beta_{1}=\left(I_{p} / L_{y}\right)^{\alpha}, \quad \beta_{2}=\left(I_{p} / L_{y}\right)^{\alpha-1}$

Thus, domestic inflation can be expressed as a function of imported inflation and domestic wage cost and the parallel rate:

$$
\begin{gathered}
\dot{P}_{y}=\beta_{1}\left[P_{m}^{*} \dot{b}+b \dot{P}_{m}^{*}\right]+\beta_{2} \dot{w} \\
=\beta_{2} \dot{w}+\beta_{3} \dot{b}+\beta_{4} \dot{P}_{m}^{*} \\
\text { for } \quad \beta_{2}>0, \beta_{3}>0, \beta_{4}>0
\end{gathered}
$$

Where a dot over a variable denotes change over time.

Equation (3) can be rearranged to solve for imports of producer goods. Substituting for $P_{y}$ from equation (7) as well, the optimal level of imported producer goods is stated as:

$$
I_{p}=\sigma(1-\alpha) Y
$$

where $\sigma=\beta_{1}+\beta_{2}\left(w / P_{m}\right)$

where $\left(w / p_{m}\right)$ is the ratio of marginal productivity of labour and imported capital inputs used for home goods production.

Since change in real exchange rate reflects change in the relative price of tradables to non-tradables, or $r=\left(e P^{*}{ }_{x} / P_{y}\right)$, then change in the parallel exchange rate affects the real exchange through its effect on domestic inflation (equation 8). In this definition of real exchange rate the relation between real exchange rate and export is defined as: $(\partial X / \partial r)>0$, so that appreciation in real exchange rate induces non-oil commodity exports.

\subsection{Household Portfolio Allocation}

Households choose between domestic and foreign assets, a portfolio allocation decision. Households' nominal financial asset portfolio $H$ is assumed to consist only of domestic money holdings $M$, and foreign money holdings $F^{6}$. Since households buy foreign currency $F$ only in the parallel market, and therefore value it at the parallel exchange rate $b$, the domestic currency value of households' nominal wealth $H$ can be expressed as:

\footnotetext{
${ }^{6}$ As the stock market is underdeveloped, its impact on domestic savings is negligable.
} 
$H=M+b F$

Let $\lambda$ be the fraction of financial wealth $H$ that households want to hold in foreign currency. Both foreign currency $F$ and domestic currency $M$ earn zero interest, but $F$ will provide a return whenever the parallel rate $b$ changes. ${ }^{7}$ The fraction $\lambda$ will therefore rise with the actual rate of increase in the parallel rate.

In equilibrium, desired holdings of foreign money $\lambda H$ must equal the actual stock $b F$ of foreign money being held, so we can solve for $H=b F / \lambda$. Replacing $H$ in the equation (10) and rearranging to solve for $M$, and then dividing both sides by e, to convert to foreign currency values, valued at the official rate, so that:

$$
m=[(1-\lambda) / \lambda)] \pi F
$$

Where $\mathrm{m}=\mathrm{M} / \mathrm{e}$. The fraction $\lambda$ is a function of the rate of increase in parallel rate, but this can be broken down into appreciation of the official rate, $\hat{e}$, and of the parallel market premium $\hat{\pi}$. Under fixed official rate, parallel market rate change equals to change in the parallel premium rate. Thus letting $\Lambda(\hat{\pi})$ stand for the relationship of $(1-\lambda) / \lambda$ and solving for $\hat{\pi}$ equation (11) can be expressed as:

$$
\hat{\pi}=\Psi(m / \pi F) \quad \Psi^{\prime}<0
$$

Equations (11) and (12) represent the portfolio-balance or the asset market equilibrium condition. Equation (11) indicates that the higher the expected rate of increase of the parallell rate (depreciation), the lower is the ratio of domestic money to foreign currency holdings.

\subsection{Government Decisions}

The government determines much of the context for decisions of other agents in the economy, and also acts as a separate agent. For instance, the government decrees and administers a set of foreign exchange controls which regulate entry into the official exchange market. In this market the government buys foreign currencies from households at the official rate $e$ and allocates it to pay for government imports $(G)$. The government can buy from only one source: private sector export revenue $X$.

We assume that government spending $G$ is entirely spent in imports, including payment of interests on foreign debt, and that no new foreign debt is incurred. Further, we assume that any of $G$ that is not financed by taxes must be financed by borrowing from the Central Bank.

The change in the stock of domestic money $M$ is equal to the change in central bank domestic credit, $D$, plus the change in (domestic currency value of) foreign currency reserves held by the government, $e R$. The change in domestic credit reflects government borrowing

\footnotetext{
${ }^{7}$ A principal motive of holding domestic money despite its zero interest earning, because of zero risk of holding it.
} 
from the central bank to finance its deficit, $G-T$ or (in foreign currency) $g-t$ (where t=T/e, and $\mathrm{g}=\mathrm{G} / \mathrm{e}$ ) that is,

$$
\begin{aligned}
\dot{m} & =\dot{D}+\dot{R} \\
& =(g-t)+\dot{R}
\end{aligned}
$$

Since $(M / e)=m$

The value of $\dot{R}$ is determined in the official exchange market, to which we now turn.

\subsection{Foreign Exchange Markets}

\subsubsection{The Official Reserves}

The current account balance in the official market (for brevity we will call it official resrves) ${ }^{8}$, $\dot{R}$, is determined as a fraction of export revenue channelled through the official exchange market, $((1-\phi) e X)$, less government imports $(G)$ all valued in foreign currency. Algebraically, the official reserves can be expressed as:

$$
\dot{R}=[(1-\Phi) X(r)]-g
$$

Where $\mathrm{r}$ is the real exchange rate. Substituting for $\Phi$ (equal to $(1-1 / \pi)$ ) from equation (5) yields the final form of the official reserves:

$$
\dot{R}=(X(r) / \pi)-g
$$

Thus, the status of the official reserves is affected by the real exchange rate and the parallel rate premium. For example, as implied by equation (5) rising parallel rate premium affects the official reserve balance inversely through the smaller proportion of export proceeds allocated to the official foreign exchange market. It can also be verified from equation (15), as adverse shocks to export raise the parallel premium, balancing official current account, $(\dot{R})$ and requiring fiscal deficit reduction $(\mathrm{g})$.

\subsubsection{The Parallel FX Market}

After determining the official current account, the current account in the parallel market, $\dot{F}$, is determined by subtracting total imports (private sector and government), capital flight and official reserves, from the total inflow of foreign currency to the economy:

\footnotetext{
${ }^{8}$ There are no capital account transactions in the official market.
} 


$$
\dot{F}=X(r)-\left(I_{p}+g\right)-C-\dot{R}
$$

Where $I_{p}$ represents imports of producer goods, and $C$ is the capital flight measured in foreign currency units. Since there is no commonly accepted definition of capital flight in the economic literature, in this paper we define capital flight in more broader terms as the outflow of capital from a country in response to risk and uncertainty in the economic policies of that country. As a result, given that declining official reserves and an increasing parallel rate premium calls for more stringent foreign exchange regulations, the probability of a balance of payment crisis leading to capital flight depends on the deviation of the parallel rate premium from a benchmark level that balances official current account. More formally, from equation (15) the premium level that balances official reserves $(\dot{R}=0)$ can be determined as:

$\tilde{\pi}]_{\dot{R}=0}=(X / g)$

Given that change in the ratio of capital flight to total private wealth, $(\mathrm{a}=\mathrm{C} / \mathrm{H})$, depends on the location of the premium from its benchmark level, $(\tilde{\pi})$, then:

$$
a=f(\pi-\tilde{\pi}) \quad \text { for } f^{\prime}>0
$$

Equation (17) implies a change in the ratio of capital flight, a, and depends on the official reserve status, which itself depends on whether the premium is above or below the benchmark level $(\tilde{\pi})$. Denoting $\theta=(\pi-\tilde{\pi})$ then from (17) the following relations hold: ${ }^{9}$

$$
\begin{array}{lll}
\frac{d a}{d \theta}>0 \quad \text { if } & \theta>0 \Rightarrow \dot{R}<0 \\
\frac{d a}{d \theta}<0 \quad \text { if } & \theta<0 \Rightarrow \dot{R}>0 \\
\frac{d a}{d \theta}=0 \quad \text { if } & \theta=0 \Rightarrow \dot{R}=0
\end{array}
$$

Taking into account total private financial wealth, $(\mathrm{H}=m+\pi F)$, and substituting for $\dot{R}$, from equation (15) and $I_{p}$ from equation (8) we get the final form of the current account balance in the parallel exchange market:

$$
\dot{F}=(1-1 / \pi) X(r)-\sigma(1-\alpha) Y-a(\theta)(m+\pi F)
$$

\footnotetext{
${ }^{9}$ Since capital flight in our context is defined as outflow of foreign currencies due to continuous deterioration of official reserves, it serves as a proxy variable for political uncertainty.
} 
Equation (18) completes the model, which consists of the differential equations (12), (13), (15) and (18) in $\dot{m}, \dot{F}, \dot{R}$, and $\hat{\pi}$. To simplify, we reduce the differential equation system to three equations by substituting for $\dot{R}$ into equation (13) giving:

$$
\dot{m}=(X(r) / \pi)-t
$$

The third differential equation is (12), repeated here as:

$$
\hat{\pi}=\Psi(m / \pi F) \quad \Psi^{\prime}<0
$$

The dynamic system of the model is now represented by the equations (12), (18), and (19).

In the next section we illustrate the adjusment process of the economy when speculative effects and adverse shocks hit the economy in a situation of an insufficient level of reserves.

Assuming the parallel market always adjusts to a steady state representes, $\dot{F}=0$, the adjustment process of the economy is illustrated using phase diagrams of the equations (12) and (19), under two different cases: (a) At the pre-secession period when speculation about official reserve depletion is rising; and, (b) At the post-secession era, represented by adverse export shocks to the economy.

\section{Dynamic Analysis}

It should be noted that political uncertainty in our context is due to the likelihood of the country splitting into two independent parts, resulting in a permanent adverse export shock to the economy in the North, which would lose substantial amount of oil resources. However, at the pre-secession period speculations were rising with regard to official reserves depletion and sustainabilty of the official exchange market. In the following section we analyse the dynamics of the financial system under each of the two cases.

\subsection{Speculative Effects}

As the date of the Referendum to decide upon unity or separation of the country was approaching, foreign reserves with the central bank hit low levels, as the public anticipation of future currency depreciation rose. ${ }^{10}$ The adjustment process in the financial system due to the rising demand on foreign currency in the parallel market is explained in figure (1). As indicated in the proposition, a steady-state solution exists only if the capital outflow is maintained at low levels. Given this condition is satisfied, the initial steady state equilibrium is represented at point $d$ in figure (1). Rising demand for foreign currencies in the parallel market are represented by an upward shift in the parallel rate premium from point $d$ to $q$. At point $q$ expanding spread between the official rate and the parallel rate aggravates reserve losses and induces further anticipation of an official rate devaluation, which will push the

\footnotetext{
${ }^{10}$ According to the IMF Country Report of 2009, Sudan foreign currency reserves declined from about US\$ 1.7 billion in 2006 to about US\$ 390 million in 2009.
} 
parallel rate premium at the point $\mathrm{g}$. When official reserves reach a minimum level at point $\mathrm{g}$, the government resorts to a devaluation of the official rate that brings the system to the point $\mathrm{h}$. During the adjustment process from $\mathrm{h}$ to $\mathrm{d}$, along the saddle path some of the reserves previously lost are replenished. It should be realized that the recovery process from points $\mathrm{g}$ to $\mathrm{h}$ and then to $\mathrm{d}$ depends on the level of the initial official reserves, as the lower is the official reserves level, the longer the adjustment process is expected to take. In other words, when the level of official reserves is low, the distance between points $g$ and $h$ becomes wider which requires a bigger devaluation of the official exchange rate to locate the system along the sadle path at point $h$. Thus, the adjusment process when official reserve level is low, or insufficient, is more costly in terms of the social cost pertaining to the impact of the official rate devaluation on income distribution and resources re-allocation.

Figure (1): Speculative effects and insufficient reserves

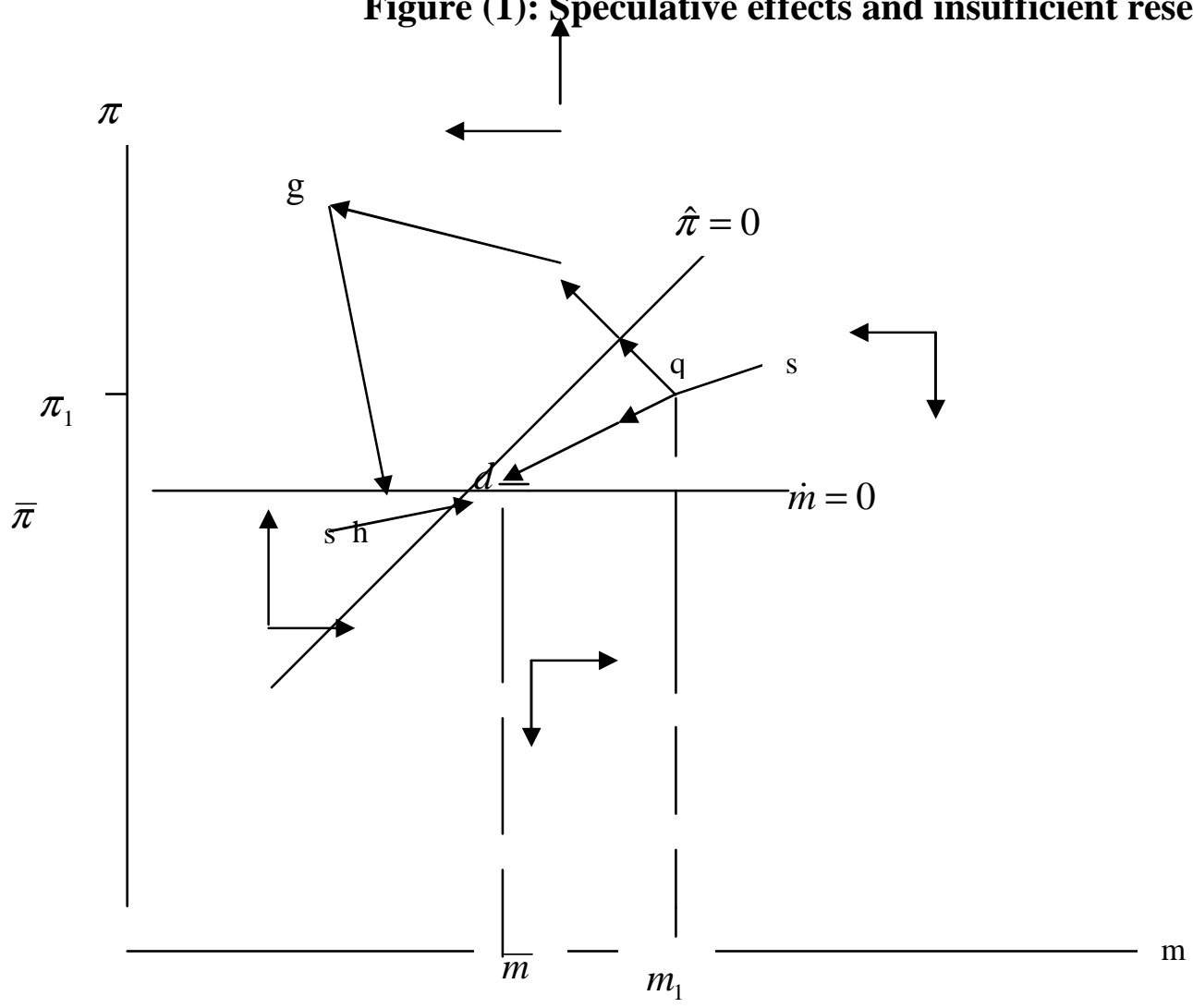

\subsection{Permanent Export Shock}

Since after secession the economy in Sudan lost the large part of crude oil export revenues, the adjusment process in figure (2) illustrates the impact of a permanent adverse shock in export which causes an upward shift in the $\dot{m}=0$ schedule to $\dot{m}^{\prime}=0$. Upon the impact, the depreciation of the parallel rate raises the premium level to the point $\mathrm{B}$. The adjustment from $\mathrm{B}$ to $\mathrm{N}$ will be affected by reduction in the demand for domestic money in private assets portfolio and the government's withdrawal from its reserves to sustain the official rate. However, by the time official reserves reach their benchmark minimum, the government resorts to discrete devaluation of the official rate so that the system jumps from $\mathrm{N}$ to $\mathrm{h}$, and then converges along the saddle path towards the new equilibrium at point $\mathrm{d}$ ' with 
international reserves partially restored, along the new saddle path s's'. It should be realized that for the adjustment process towards the equilibrium level to be feasible, it is required that the initial level of reserves must exceed losses that take place during the transition, from points d to N; otherwise, a balance of payment crisis will take place. It is also to be noted that the new steady state solution at point d' is maintained at a higher parallel premium level, reflecting a wider spread between the two exchange rates at the steady state solution. Thus, the steady state premium level depends on size of the adverse export shock. If the shock is too big, in such away that it induces intolerable spread between the two exchange rates, the government is left with the only option of unifying the exchange rates by adopting free floating rate, to which we turn in the following section.

Figure (2): Export shock

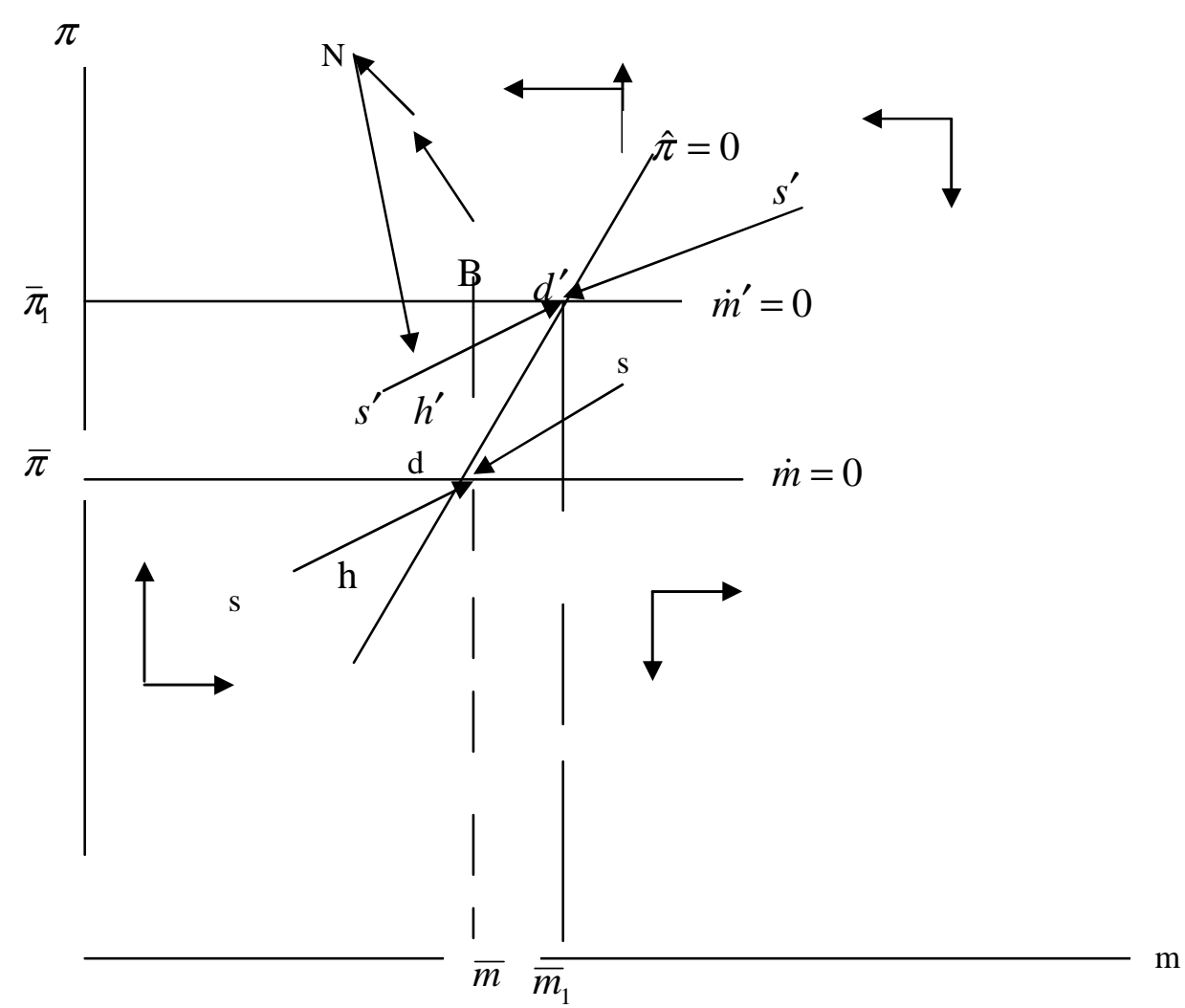

Let us assume that due to expanding fiscal deficit and deteriorating official reserves the government decided to abandon the dual foreign exchange policy and liberalize its foreign exchange market by adopting a single exchange rate floating freely and applicable to all transactions. In order to investigate the behavior of the post-unification floating exchange rate we introduce some changes into the basic model. Under a floating exchange rate system, the government eases the foreign exchange rate restrictions by allowing the private sector to buy and sell foreign currency determined by supply and demand conditions. Given the exchange rate is now flexible, there is a unified exchange rate which will be denoted by $\mu$. Since the central bank no longer intervenes in the foreign exchange market the stock of official reserves 
is constant $(\dot{R}=0)$. Under the new foreign exchange system the change in domestic money supply is reflected only by change in domestic credit: $\dot{M}=\dot{D}$, therefore

$$
\dot{m}=\left[\frac{(g-t)}{m}-\hat{\mu}\right] m
$$

where $(g-t)=(G-T) / \mu$, and $m=M / \mu$.

The condition for portfolio equilibrium under the floating exchange rate system is given by:

$$
m=\Lambda(\hat{\mu}) F
$$

Given the parallel market equilibrium condition still holds $(\dot{F}=0)$, the dynamic system of the model is now represented by the equations (20) and (21). In order to reduce the system into a single equation we invert equation (21) and substitute it into equation (20) to get:

$$
\dot{m}=\left[\frac{(g-t)}{m}-\Psi(m / F)\right] m
$$

where $\Psi(m / F)=\hat{\mu}, \quad \Psi=\Lambda^{-1}, \Psi^{\prime}<0$

Since $[(g-t) / m]=\dot{M} / M$, we denote the growth in domestic nominal money (or domestic credit expansion) by $\eta(t)$ so that equation (22) can be expressed as:

$$
\dot{m}=[\eta(t)-\Psi(m / F)] m
$$

When domestic credit expands at a constant $\operatorname{rate}^{11} \eta(t)=\eta$.

Equation (23) represents the evolution of domestic money growth under a floating exchange rate system, and it indicates that in the steady-state $(\dot{m}=0)$ the rate of exchange rate depreciation is identical to domestic credit expansion: ${ }^{12}$

$$
\hat{\mu}^{*}=\eta
$$

\footnotetext{
${ }^{11}$ The condition of constant rate of domestic credit expansion is crucial for existance of stable equilibrium values of the state variables, M, F, and $\pi$.

${ }^{12}$ The size of the public deficit $(\mathrm{g}-\mathrm{t}$ ) or domestic credit expansion does not change between the two regimes of foreign exchanges because there is no effective open market operations that allows the government to adjust its stock of money supply according to its reserve level. In otherwords, the government is always a buyer of foreign currency, not a seller of foreign currency.
} 
Equation (24) predicts that if a fiscal deficit persists after the liberalization of foreign exchange system, depreciation of foreign exchange rate will be identical to domestic credit expansion.

\section{Concluding Remarks}

The macroeconomic model employed in this paper is designed to mimic small open economies enduring political uncertainty arising from country splitting into two independent parts. The findings in the paper indicate that the stabilization of foreign exchange rates at the post-secession era depends on political stability in the country, which will impact on foreign currency inflows to the country. Our model predicts that if political unrest continues after the split of the country, then foreign currency reserves at the Central Banks of either country will dwindle over time, which may lead to domestic currency depreciation in terms of hard currencies. The model also predicts that an expanding budget deficit and declining Central Bank reserves will eventually force the government to abandon a fixed exchange rate system in favor of a more flexible exchange rate system that resulting in further acceleration of both the domestic inflation rate and the domestic money growth rate. As a result, the postsecession period is likely to be characterized by economic instability and political unrest in the two sides unless economic cooperation between the two countries is maintained. 